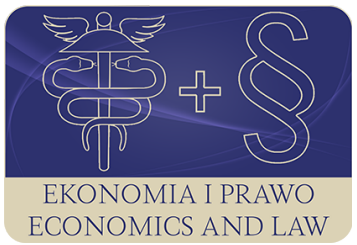

EKONOMIA I PRAWO. ECONOMICS AND LAW

Volume 16, Issue 4, December 2017

p-ISSN 1898-2255, e-ISSN 2392-1625

www.economicsandlaw.pl

ECONOMICS AND LAW

ORIGINAL ARTICLE

received 13.06.2017; revised 01.12.2017; accepted 31.12.2017

Citation: Matwiejczuk, W., \& Gorustowicz, M. (2017). Determinants of cyclical changes within the construction sector. Ekonomia i Prawo. Ecomomics and Law, 16(4): 459-470. doi:10.12775/EiP.2017.032.

\title{
Determinants of cyclical changes within the construction sector
}

\author{
WIESEAW MATWIEJCZUK \\ corresponding author \\ Białystok University of Technology, Faculty of Engineering Management, Department \\ of Organization and Management, ul. Ojca Tarasiuka 2, 16-001 Kleosin, Poland \\ $\square$ w.matwiejczuk@pb.edu.pl

\section{MARIUSZ GORUSTOWICZ} \\ Białystok University of Technology, Faculty of Engineering Management, Poland \\ $\square$ m.gorustowicz@pb.edu.pl
}

\begin{abstract}
Motivation: The specifics and operation conditions of enterprises including the construction sector companies cause sensitivity to economic fluctuations manifested in the cyclical disorders of economic activity level (business cycles). Background research work is to determine the effect of internal and external environment on a range of determinants of the economic situation fluctuations potentially occurring in the sphere of the construction sector.

Aim: The aim of this article is to present the main factors affecting economic condition fluctuations in the construction sector and their impact on company operation.

Results: The result of the study and documents analysis will include identification of factors affecting to the highest degree the economic fluctuations in the construction sector and their impact on the functioning of the enterprise. These factors will be specified from among the macro-economic environment but mainly from the internal environment of the company. Developed proposals will be useful in building the short- and long-term operation strategy for both the construction companies and the entire sphere of the construction sector.
\end{abstract}

Keywords: economic situation fluctuations; determinants; economic activity of businesses; construction sector

JEL: D24; E32; F60; L78 


\section{Introduction}

In the modern world, stable economic growth and advantageous micro and macroeconomic indicators are the aim and modus operandi of every government and individual economic organisation. Striving to fulfil entirely the ever-increasing needs of consumers and demands of the market leads to an increase in production, its variety and as a result can augment profits and raise the value of a business.

Nevertheless, economic growth is not a permanent phenomenon. Economic development occurs in phases of the so-called business cycle, and the of duration of individual phases depends on many macro and microeconomic factors, including a suitable and well-managed national economic policy and to an increasing degree, on various economic instruments used by international organisations. The participation of supra-national economic entities in the economic life of countries is not only becoming significant, but also slipping out of their control (Klamut, 2007, p. 21). Finding effective countermeasures to offset the negative effect of uncontrolled factors on business is extremely difficult. A sector that is particularly dependent on and sensitive to economic fluctuations is the construction sector. The sensitivity of the construction sector to economic changes is visible among others in the cyclic changes in the level of economic activity of businesses, their financial condition and level of employment.

Extensive knowledge on the essence, process and consequences of potential economic fluctuations and the ability of businesses to prepare themselves are a resultant of the state and development of the economy, both on a national and on a global scale. A business with a large depth of knowledge can react accordingly and prepare itself for the effects of economic fluctuations. Intuitively, entrepreneurs have a tendency to start new businesses when optimistic economic outlook prevails (Fan et al., 2016, p. 159). An awareness of the potential disadvantageous consequences of economic fluctuations and the possibility of counteracting them can be an exceedingly important factor in the financial state and competitiveness of a business, or even an entire sector. Macroeconomic developments, such as the business cycle, have a remarkable influence on firms and their performance (Frosen et al., 2016, p. 91). The creation of a catalogue of factors affecting economic fluctuations, especially in the construction sector, is essential from not only an economic, but also a business point of view. The analyses of economic fluctuations in the construction sector in recent periods carried out in this article allow us to specify those factors which determine the conditions of development for construction businesses and their competitiveness to the greatest degree. The background research of this study was to determine the effect of the internal and external environment on the range of potential determinants of economic fluctuations in the construction sector.

The aim of this article is therefore to present the main factors affecting economic fluctuations in the construction sector and their effect on the functioning 
of businesses. These factors will be specified from the macroeconomic environment, but above all from the internal environment of the business.

\section{Literature review}

Since the beginning of its existence the market economy has grown at a varying rate. An important research aspect in considering its nature and determinants are the changes of economic activity described in literature as business cycles. This phenomenon was first studied by A.F. Burns and W.C. Mitchel (1946, p. 3 ), who defined them as a type of a fluctuation found in the aggregate economic activity of nations that organize their work mainly in business enterprises. They are made up of phases of growth occurring at the same time in numerous economies followed by crises, periods of stagnation or recovery which combine with the growth phase of the next cycle. These first indications became the foundations of the current research trend focusing on economic conditions.

Today, most modern business cycle theories assume that fluctuations are driven by changes in current fundamentals such as aggregate productivity. Within the last several years we have witnessed a revival of an older theory in which business cycles can arise without any change in fundamentals (Barsky \& Sims, 2011, p. 273).

In Economy the business cycle is perceived as macroeconomic fluctuations and fluctuations around a potential economic trend (Kucharska-Stasiak, 2016, p. 97). This especially concerns the aspect of macroeconomic fluctuations: conditions under which economic activity occurs undergo further changes there is a change in product supply, in product characteristics, in interest rates and level of employment. This approach is a reflection of the classic definition of the cycle and focuses on the study of economic activity within the absolute approach. A cycle consists of growth occurring at the same time in numerous sectors of the economy followed by a crisis, depression or recovery (Lis, 2012, p. 36). In respect to the fluctuations around the trend of a potential economic growth: an economy which is above its potential growth is within the development phase while one that is below is in the recession phase. This definition reflects the contemporary concept of the cycle and currently has the most advocates (Lis, 2012, p. 37).

Within the construction sector changes in the economic and social environment mainly have a strong impact on the real estate market. The housing market is especially sensitive to the economic situation of households and, consequently, to changes in demand generated by households as well as preferences regarding the characteristics of dwellings being purchased (Foryś 2011, Bryx 2006). This is the effect of the cumulative impact of several varying in strength and direction economic, institutional or political factors. The most significant among those include: changes in the mechanism of the market, intensifying structural transformations, an increase in the level of openness of modern economies, i.e. an increased importance of the movement of goods and manufacturing factors 
on an international scale, phenomena and crisis processes in the currency sector and changes in the objectives and instruments used by government bodies to influence economic processes. (Barczyk et al., 2006, p. 144). A common perception among economic observers is that macroeconomic fluctuations are not driven only by current developments in the economy but are often influenced by perceptions of future developments, that is, they may be driven by changes in expectations about fundamentals as opposed to current changes in opportunities or preferences (Beaudry \& Portier, 2007, p. 458).

\section{Characteristics of the construction sector in Poland and its vulnerability to fluctuations}

The construction sector and the firms that form it are an important part of the European and, even more so, the Polish economy. In some countries, the real estate and construction sector is responsible for as much as one quarter of gross domestic product (GDP) and 70\% of national wealth and employs up to $20 \%$ of the workforce.

In Poland, the construction sector has been subjected to various internal and external influences over the last 27 years, which have been reflected in substantial economic fluctuations and changes. Most significantly, the 1990s and especially the period 1995-1999 experienced a huge boom in construction, which alongside the favourable economic condition led to a gradual improvement in the economic situation of Poland. In addition, a large expansion of the service sector in foreign direct investment and the difference in expansion in income resources resulted from their significant (and different in each case) dynamics in the years 1990-2001(Kłosiński \& Masłowski, 2005, p. 50).

Nevertheless the beginning of the new millennium (the years 2000-2004) brought a collapse in construction and initiated the period of global recession. This crisis caused restrictions in the activity and scope of many areas of the economy linked to construction. Faced with low domestic demand, producers rescued themselves by exporting building services. Among the causes of such a deep regression in construction are: a clear decrease in the scope of investment; the withdrawal of most forms of preferential relief for construction; increased competition from foreign firms; increased competition between domestic firms, which led some of them to bankruptcy (Bolkowska, 2007).

The years 2005-2007 constituted a short period of boom in construction, during which there was a sharp rise in production (over $15 \%$ each year). This is another economic expansion, initiated to a large degree by Poland's accession to the European Union and the increased level of economic aid coming from the EU. This resulted in demand on the domestic investment market, which was reflected in the improved state of the construction sector. In 2008 a weakening of the construction-investment market occurred, caused by a crisis in the global financial markets. Initially the effects of disturbances on the global financial markets on the economies of countries such as Poland were restricted mainly 
to capital markets, however they later spread also to individual sectors, including the construction sector. The years following the crisis constitute a period of stagnation that has lasted until the present day. The sector remains saddled with difficulties in maintaining financial liquidity, which in turn leads to payment backlogs and bankruptcy for many firms. Hope for an improvement of this situation can be found in the new financial perspective of 2014-2020, however whether this occurs successfully and effectively no longer depends primarily on the construction sector.

An analysis of the statistical data of construction shows that the rate of development of Polish construction is characterised by huge fluctuations, which causes it to stand out in a negative light when compared with the stable development of EU construction (chart 1). The above fluctuations cause adequate difficulties in the stabilising of the production potential of firms and in the rational allocation of resources (Matwiejczuk \& Samul, 2013, p. 117). Economic fluctuations in construction, revealed above all in changes in levels of investment, the value of construction production, employment levels, the price level etc. are a result of the developmental processes that occur in the economy. Chart 2 illustrates the breakdown of the general economic climate in construction by year. Long-term trend analysis confirms extensive cyclical fluctuations within the Polish construction industry which, to a large degree, hampers the operation of such businesses.

As a result, the following research hypothesis has been established: Conditions resulting from the closest environment (microenvironment) have the greatest impact on the stability of construction enterprises and economic downturns within the sector magnify problems impeding their development.

\section{Methods}

The subject of research in this article is determining the significance of main factors affecting cyclic abnormalities in the level of economic activity of businesses in the construction sector, their essence, process and the consequences of the continued functioning of the business. An important objective is to identify those factors which determine the conditions for the development of construction businesses and shape their competitiveness to the greatest degree.

The research was carried out on businesses from the construction sector which are active in Poland, grouped according to their size: from micro-businesses to small and medium businesses, to large construction corporations. The characteristics of the businesses with regard to the details of their operation were not narrowed down to either the service layer or the production layer. The largest possible range of measures was used in order to reach a numerous group of businesses from the construction sector. In order to gain concrete and confirmed arguments to form certain theses, a range of research tools were used, thanks to which the final results can be the basis of further academic discussion, including further research on this phenomenon. A critical review of subject lit- 
erature has also been carried out in the presented article, as well as research on documents in the form of descriptive statistics and analysis and synthesis.

In the main empirical research, it was decided that an indirect method of quantitative research, namely questionnaires, should be used, with both internet PAPI (Paper and Pencil Interview) and conventional (reaching the respondent directly) questionnaires. This choice was made based on the specificities of the research sample and in order to increase the effectiveness of the research. The internet questionnaires were carried out in the period of January-March 2017 using the e-mail of one of the largest internet services for creating questionnaires and tests. Randomly selected businesses were sent invitations with links to a web page, on which the questionnaire on the importance and hierarchy of the potential range of determinants of economic fluctuations in the construction sector and their effect on the functioning of the business was placed. Altogether around 200 links to the web page were distributed. 55 correctly completed questionnaires were received, of which 2 were discarded as a result of gap in the participant's data in the questionnaire. Therefore 53 questionnaires qualified for final analysis.

The authors of this article are aware of the fact that the sampled group of businesses is not fully representative and treat this as a pilot study, which could later form the basis of further research.

\section{Results}

The term 'economic situation' is most often used to signify the state of economic activity in businesses and the changes this state undergoes, including the state of the main determining factors (e.g. supply, demand, hiring, investment) (GUS, 2016, p. 5). The characteristics of businesses, including construction businesses, and conditions under which they operate lead the sector to be directly sensitised to economic fluctuations, which can be observed in business cycles. Firms in the construction industry have always had to deal with the challenges of the economic cycle and develop strategies to deal with the resulting fluctuations in their business environment (Ruddock et al., 2014, p. 225).

The background research of this paper was determining the effect of the external and internal environment on the range of potentially occurring determinants of economic fluctuations in the construction sector. There are many sources of this state, however as Griffin (2013, pp. 75-89), points out from the point of view of an organisation, the organisation's environment, divided into external and internal, conditions the functioning of the business. In addition, three basic categories can be used to explain the effect of the environment on organisations: the variability and complexity of the environment, the strength of competitors and interferences in the environment.

In the questionnaire that was prepared for the purposes of this research, three groups of potential factors conditioning the business climate were indicated: 
- exogenous (external) factors, split into: global, national (mostly shaped by state interventionism), regional and local;

- endogenous (internal) factors where the focus was placed mainly on internal business factors, resulting from the specificities of their operation;

a comparison of the effect of individual groups of factors.

Additionally, in order to ensure answers were specific, respondents were asked to provide specific data regarding the size of the business and length of time it had been functioning in the market.

In the structure of the studied businesses, the largest group was microbusinesses - over $58 \%$, followed by small - over $29 \%$, medium - $6 \%$ and large $-6 \%$ businesses. In terms of the length of time they had been functioning on the market, most respondents that provided an answer said they had been functioning for over 10 years - 64.5\%, followed by firms that had been functioning for up to 5 years - $25.8 \%$ and those that had been functioning for $5-10$ years. An analysis of the specified data points to the fact that most answers were received from firms that had been functioning for over 10 years, with the status of micro or small businesses. This is significant from the point of view of the analysed topic, where time constitutes an important aspect of the process of economic fluctuations, and firms having been in business for over 10 years have considerable market experience and knowledge about the specificities of the sector, meaning the data is much more reliable.

A comparison of the basic groups of factors shows that internal factors have the greatest direct influence on the functioning of businesses (table l). Businesses indicated that internal factors were from their point of view the most important, and constituted a significant determinant of economic fluctuations in the construction sector. The average score of this group of factors was 5.63 (on a 7 point scale). Among the external factors that had the lowest effect on the economic situation of businesses were global factors (average score 3.63).

Among the internal determinants, some particularly important factors were: correct management decisions regarding the functioning of the business in times of both recession and boom along with having highly qualified employees (average score over 6 points, median 7). Slightly lower (average scores of 5.90 points and 5.80 respectively, and a median of 6) scores were recorded for the continuous monitoring of the environment both close to the business and further afield (competition, clients, suppliers) and well thought through investment of profits in development, creating a buffer for periods of decline in the sector. The remaining four factors in this group were given lower scores, nevertheless compared with factors from other groups, they still scored highly (table 2).

The results received point directly to the fact that all market activities begin with the decisions of individual business owners. It is they who create, steer and drive not only their own firms, but also have a significant influence on the macroenvironment. Analysing the received data from the first part of the study regarding exogenous factors, it should be noted that in the group of global determinants, the factor which had the most significance was rapid technolog- 
ical advances (average score 4.80 points), and the factor which had the least significance was integration processes of countries (average score 2.90 points). This is an important aspect of the study which indicates that on a global level, rapid technological advances can have a significant effect on the business climate in construction.

Among national factors, the study indicated a considerable effect of national fiscal policy, stimulating or restraining economic activity according to the needs resulting from the course of the business cycle (average score 5.29 points) as well as the increase of investment and financial expenditure directly from the national budget and external subsidies e.g. from the EU (5.19 points). The factors with the lowest significance according to respondents were those regarding the national monetary policy and protectionism with regard to foreign trade (tariffs, quotas, embargos and non-tariff barriers) (average score 3.3-3.5 points). Obtaining such results seems to be dictated by certain changes, in both the micro and macro environment, which can be observed thanks to, for example, EU funds as well as the widening of the platform of cooperation of firms in the construction sector, both with regard to technology and to their order portfolios.

With respect to regional and local factors the largest proportion of responses indicates the importance of factors regarding pro-business policies of local authorities (average score 5.40 points) as well as cooperation with national control bodies (average score 4.30 points). The factor that was indicated the least was cooperation with business environment institutions (average score 3.87 points). These results point to the fact that the policies of authorities closest to businesses have a large significance with regard to the operation of businesses in the construction sector, combined with the role of national control bodies, which can influence the market and its state. The small proportion of respondents indicating BEI could signify that they are not direct 'players' on the market, but only a factor influencing the institutions and market in the construction sector to a lesser degree.

\section{Conclusion}

Economic fluctuations in the construction sector are, similarly to in other sectors of the economy, a result of the state of the economy and its dependencies on internal and external factors. Comparing the strength of individual factors is key in order to understand the mechanisms of the operation of businesses in a complex business environment. The results of this study confirm the large interest of firms in discovering the forces that could influence the state of their organisations. The fact that the greatest interest of firms is geared towards internal factors can be explained by the sense and need to increase their own possibilities of affecting economic reality. It is also an expression of the strength of a business on the market that, grouped into a sector (in this case the construction sector), can influence the taking of remedial action against the negative effects of economic fluctuations. 
It should be noted that the level of internationalisation of businesses in the construction sector grows from year to year, as will therefore the role of external factors. However, despite increased opportunities to acquire current economic information on the state of national economies, as well as the international environment, predicting the occurrence of the next phase of the business cycle, for example a recession, is very difficult. That is also why the indicated determinants of economic fluctuations in the construction sector, in conjunction with the mechanism of the business cycle, can form a system of dependencies, which in our present, highly unpredictable world, will continually evaluate and deliver new information and arguments for further research in this area. The applicational nature of this research will consist of the elaboration of recommendations for short and long term operating strategies which will be useful to firms in the construction sector. The search for reliable information, which is necessary in order to react and prepare businesses for the effects of a possible recession in the right way, is nowadays one of the most important tasks of an organisation.

\section{References}

Barczyk, R., Kąsek, L., Lubiński, M., \& Marczewski, K. (2006). Nowe oblicza cyklu koniunkturalnego. Warszawa: PWE.

Barsky, R.B., \& Sims, E.R. (2011). News shock and business cycles. Journal of Monetary Economics, 58(3). doi:10.1016/j.jmoneco.2011.03.001.

Beaudry, P., \& Portier, F. (2007). When can chanes in expectations cause business cycle fluctuations in neo-classical settings? Journal of Economic Theory, 135(1). doi:10.1016/j.jet.2006.06.009.

Bolkowska, Z. (2007). Budownictwo w latach 1995-2006. Retrieved 07.03.2017 from http://www.muratorplus.pl.

Bryx, M. (2006). Rynek nieruchomości. System i funkcjonowanie. Warszawa: Poltext.

Burns, A.F., \& Mitchell, W.C. (1946). Measuring business cycles. NBER Book Series Studies in Business Cycles, 2. New York: NBER.

Eurostat. (2017). Construction production. Retrieved 27.03.2017 from http:// www.eurostat.ec.europa.eu.

Fan, H.C., Gao, X., Xu, J.Y., \& Xu, Z.W. (2016). News shock, firm dynamics and business cycles evidence and theory. Journal of Economic Dynamics \& Control, 73, doi:10.1016/j.jedc.2016.09.010.

Foryś, I., (2011). Spoteczno-gospodarcze determinant rozwoju rynku mieszkaniowego $w$ Polsce. Ujęcie ilościowe. Szczecin: WN US.

Frosen, J., Jaakkola, M., Churakova, I., \& Tikkanen, H. (2016). Effective forms of market orientation across the business cycle: A longitudinal analysis of business-to-business firms. Industrial Marketing Management, 52. doi:10.1016/j.indmarman.2015.05.012.

Griffin, W.R. (2013). Podstawy Zarządzania Organizacjami. Warszawa: PWN. 
GUS. (2016). Badanie Koniunktury Gospodarczej. Zeszyt metodologiczny zaopiniowany przez Komisję Metodologiczną GUS. Retrieved 02.03.2017 from http:// stat.gov.pl.

GUS. (2017). Business tendency survey in industry, construction, trade and services 2000-2017. Retrieved 02.03.2017 from http://stat.gov.pl.

Klamut, M. (Ed.). (2007). Polityka ekonomiczna. Wspótczesne wyzwania. Warszawa: PWN.

Kłosiński, A., \& Masłowski, A. (2005). Globalizacja sektora ustug w Polsce. Warszawa: PWE.

Kucharska-Stasiak, E. (2016). Ekonomiczny wymiar nieruchomości. Warszawa: PWN.

Lis, P. (2012). Wahania cykliczne rynków mieszkaniowych. Aspekty teoretyczne i praktyczne. Toruń: Adam Marszałek.

Matwiejczuk, W., \& Samul J. (2013). Zarządzanie kapitatem ludzkim a konkurencyjność przedsiębiorstwa budowlanego. Białystok: Oficyna Wydawnicza Politechniki Białostockiej.

Ruddock, L., Kheir, A., \& Ruddock, S. (2014). UK construction companies' strategies in the face of business cycles. International Journal of Strategic Property Management, 18(3). doi:10.3846/1648715X.2014.927400.

\section{Acknowledgements}

Author contributions: authors have given an approval to the final version of the article. Authors contributed to this work equally.

Funding: this research was fully funded by the Białystok University of Technology, Faculty of Engineering Management, Department of Organization and Management statutory sources (S/WZ/3/2015)

Note: the results of this study were presented at 9th International Conference on Applied Economics Contemporary issues in Economy (June 22-23, Torun, Poland). 


\section{Appendix}

Table 1.

The direct influence of individual groups of factors on the functioning of businesses

\begin{tabular}{lccc}
\hline Factors / score on a scale of 1-7 & Average score & Significance (in \%) & Median \\
\hline global factors & 3.63 & 14.28 & 3 \\
national factors & 4.15 & 20.85 & 5 \\
regional and local factors & 4.40 & 24.28 & 6 \\
internal factors & 5.63 & 26.28 & 6 \\
\hline
\end{tabular}

Source: Own preparation based on Eurostat (2017).

Table 2 .

The influence of individual factors from the internal factors group on the functioning of the business

\begin{tabular}{|c|c|c|c|}
\hline Factors / score on a scale of $1-7$ & Average score & Significance (in \%) & Median \\
\hline the level of innovativeness of technology used & 5.0 & 22.14 & 5 \\
\hline $\begin{array}{l}\text { the elasticity of the business strategy taking into account the situ- } \\
\text { ation on the market and the speed at which it can react to market } \\
\text { changes }\end{array}$ & 5.42 & 24.00 & 5 \\
\hline $\begin{array}{l}\text { correct management/board decisions regarding the functioning } \\
\text { of the business in times of both recession and boom }\end{array}$ & 6.16 & 27.28 & 7 \\
\hline $\begin{array}{l}\text { well thought through investment of profits in development, creat- } \\
\text { ing a buffer for periods of decline in the sector }\end{array}$ & 5.80 & 25.14 & 6 \\
\hline the management team taking initiative & 5.20 & 21.85 & 6 \\
\hline having highly qualified employees & 6.23 & 26.71 & 7 \\
\hline running a business with a forward-looking production profile & 5.28 & 21.14 & 6 \\
\hline $\begin{array}{l}\text { continuous monitoring of the environment both close to the busi- } \\
\text { ness and further afield (competition, clients, suppliers) }\end{array}$ & 5.90 & 26.14 & 6 \\
\hline
\end{tabular}

Source: Own preparation. 


\section{Chart 1.}

The construction production trend in the EU and Poland in the years 1995-2016 $(2005=100)$

160

140

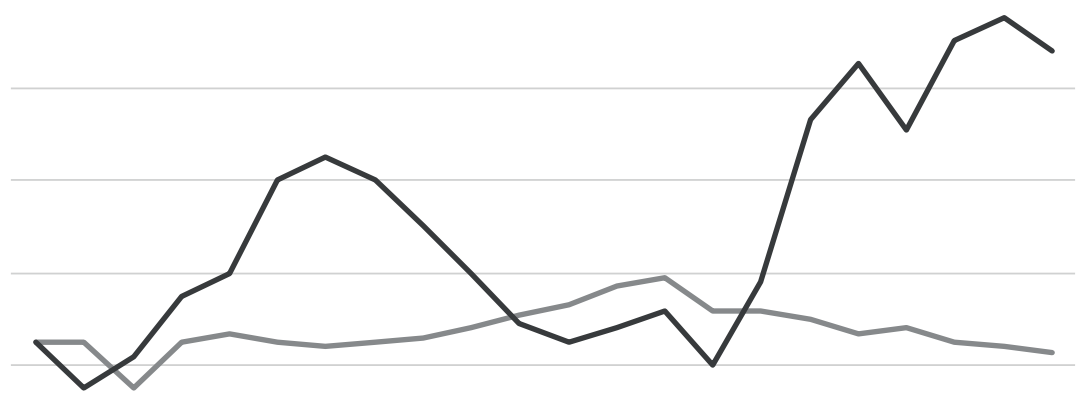

60

$\begin{array}{lllllllllll}1995 & 1997 & 1999 & 2001 & 2003 & 2005 & 2007 & 2009 & 2011 & 2013 & 2015\end{array}$

-UE Poland

Source: Own preparation based on Eurostat (2017).

Chart 2.

Economic fluctuations in construction in the period 2000-2016

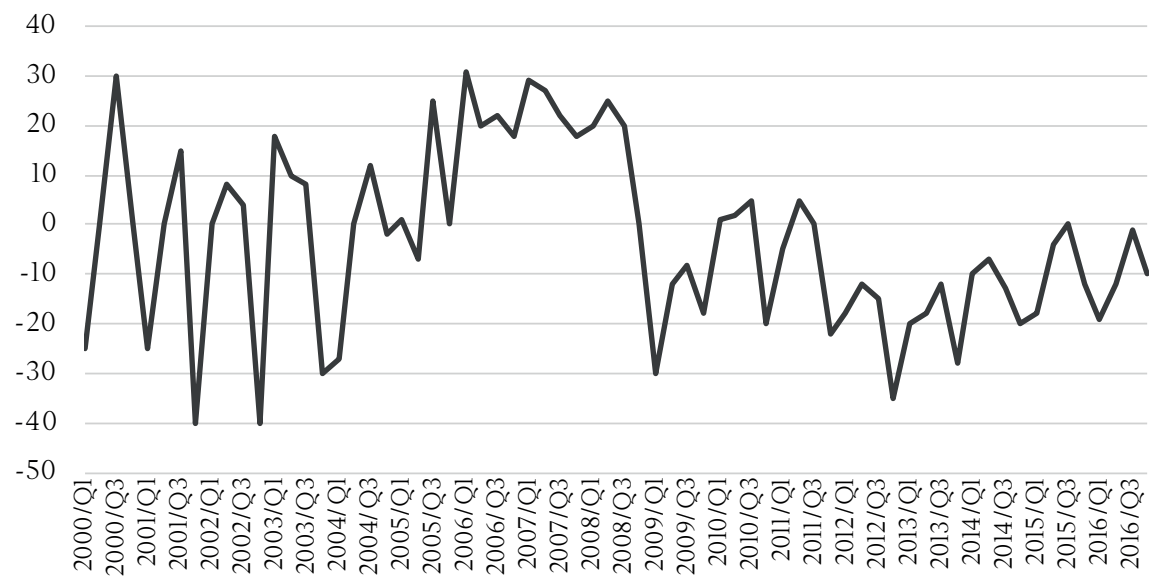

Source: Own preparation based on GUS (2017). 